\title{
The Use of Indigenous Probiotic Halomonas aquamarina and Shewanella algaefor White Shrimp (Litopenaeus vannameiBoone) Hatchery Productivity in Zero Water Discharge System
}

\author{
Gede Suantika*, Pingkan Aditiawati, Dea Indriani Astuti and Zarah Fazri Khotimah \\ Microbial Biotechnology Research Group, School of Life Sciences and Technology, Institut Teknologi Bandung, JI.Ganesha 10, Bandung 40132, Indonesia
}

\begin{abstract}
This research was aimed to improve the performance of white shrimp postlarvae culture through the application of indigeneous probiotic bacteria, Halomonas aquamarina and Shewanella algae in zero water discharge system. The research was conducted by following two consecutive steps: (1) pathogenicity test of both probiotic in white shrimp culture, and (2) probiotic effect test to water quality and vibriosis syndrome control. From the first step, the use of probiotics had no pathogenocity effect to shrimp PL since survival rate of $84-98 \%$ was documented. From step two, the application of both probiotic bacteria was able to inhibit the population growth of $V$. harveyi in which the highest survival rate of $93.94 \%$ obtained from $H$. aquamarina addition, followed by $S$. algae addition (92.12\%), H. aquamarina: S. algae addition (90.60\%), S. algae: V. harveyi addition (89.39\%), H. aquamarina: S. algae: V. harveyi addition (87.87\%), H. aquamarina: V. harveyi addition (87.57\%), no addition of bacteria $(84.84 \%)$ and V. harveyi addition $(82.42 \%)$. There was no significantly different $(p>0.05)$ among the treatments on all water quality parameters which were still in tolerance range of white shrimp PL culture (salinity $26-30 \mathrm{ppt}$; temperature $26-28^{\circ} \mathrm{C}$; $\mathrm{pH}$ 7.5-8.5; DO 5.7-6.4 $\mathrm{mgL}^{-1}$; ammonia 0.1-0.5 $\mathrm{mgL}^{-1}$; nitrite $0.02-0.25 \mathrm{mgL}^{-1}$; nitrate 5-40 $\mathrm{mgL}^{-1}$ ). In term of other biological parameter, the use of these probiotics was significantly affecting the weight increase of shrimps. Bacterial identification showed that there was a major similarity of microbial diversity found both in water and L.vannamei intestine. It could be concluded that the use of $\mathrm{H}$. aquamarina and $\mathrm{S}$. algae as indigene probiotics contributed to the increase of shrimp survival rate. However this effect was not clearly described by the effect of water quality parameters improvement and it most probably due to the inhibition activity of these two probiotics on $\mathrm{V}$. harveyi.
\end{abstract}

Keywords: L. vannamei; Postlarvae culture; Probiotic; V. harveyi; $H$. aquamarina; S. algae

\section{Introduction}

Fishery as main food source for human has been limited due to over exploitation, pollution, and disturbance of natural balance. One of way to meet demand of food from fishery is aquaculture, as a system to cultivate aquatic organism as a food source under human control, involving at least one step of aquatic organism life cycle to increase culture productivity [1]. Several aquatic organisms have been cultured in aquaculture, such as many kinds of fish and shrimp [2]. Aquaculture has important role either in national or global economical development, since it has the fastest growth of food industry ( $9.6 \%$ each year). As one of the biggest aquaculture producer, Indonesia has growth of $10.26 \%$ annually [3].

In 2008, total aquaculture production in the world reached the point of 52.5 million metric tons, which $40 \%$ of them was contributed by modern aquaculture. Crustacean production as one of the important commodity contributed up to around $62.5 \%$ of total crustacean production in the world [4].

One of the main aquaculture commodities of crustacean group in Indonesia is shrimp, especially white shrimp (Litopenaeus vannamei Boone.) as one of Penaeidae shrimp, which has high economical and nutritional value and contributes to $50 \%$ of total world production [5]. This commodity contributes significantly to the total of Indonesian aquaculture productions and by 2003 reached 115.441 ton or $47.61 \%$ of world production total [6]. However there are still many disadvantages attributed to the culture particularly low culture productivity during hatchery phase, due to the application of batch culture system which does not pay attention in water quality and disease management. Low water culture management triggers increasing of white shrimp disease infection $[7,8]$.
One of the main disease infection of white shrimp culture is vibriosis syndrome, due to Vibrio harveyi infection when it population reach more than $10^{4}$ Colony Forming Units. $\mathrm{mL}^{-1}$ (CFU.mL $\left.{ }^{-1}\right)$ [9]. Several ways have been applied to solve this problem i.e., use of recirculation system, antibiotic, chlorine, and disinfection. However, limited of simplicity and reliability recirculation system make it difficult to be applied in traditional hatchery. In addition, use of chlorine, antibiotic and disinfection support the increase of resistant bacteria strain population and accumulation of residue in the water [10,11]. Some kinds of bacteria, called probiotic bacteria, have been found to solve ineffective methods above. However, until now the application of probiotic is still limited because unresolved action mechanism of each probiotic, and questionable of probiotic as indigene or local bacteria in white shrimp culture [7].

Based on the above explanation, the research about the use of local probiotic application in white shrimp static culture system to increase water quality and to solve vibriosis syndrome is needed. In this research

*Corresponding author: Gede Suantika, Microbial Biotechnology Research Group, School of Life Sciences and Technology, Institut Teknologi Bandung, Jl.Ganesha 10, Bandung 40132, Indonesia, Tel: +62-22-251-1575; E-mail: gsuantika@sith.itb.ac.id

Received July 20, 2013; Accepted September 16, 2013; Published September 25,2013

Citation: Suantika G, Aditiawati P, Astuti DI, Khotimah ZF (2013) The Use of Indigenous Probiotic Halomonas aquamarina and Shewanella algae for White Shrimp (Litopenaeus vannamei Boone) Hatchery Productivity in Zero Water Discharge System. J Aquac Res Development 4: 194 doi:10.4172/21559546.1000194

Copyright: (c) 2013 Suantika G, et al. This is an open-access article distributed under the terms of the Creative Commons Attribution License, which permits unrestricted use, distribution, and reproduction in any medium, provided the original author and source are credited. 
Citation: Suantika G, Aditiawati P, Astuti DI, Khotimah ZF (2013) The Use of Indigenous Probiotic Halomonas aquamarina and Shewanella algae for White Shrimp (Litopenaeus vannamei Boone) Hatchery Productivity in Zero Water Discharge System. J Aquac Res Development 4: 194 doi:10.4172/2155-9546.1000194

Page 2 of 8

two kinds of probiotic that had been isolated were used, Halomonas aquamarina and Shewanella algae [12]. This research was aimed to determine effect of these two probiotics application to white shrimp culture water quality, survival and growth of white shrimp.

\section{Materials and Methods}

\section{Research preparation}

Litopenaeus vannamei postlarvae-4 (PL-4) was obtained from Suritani Pemuka hatchery, Anyer, Indonesia. It was acclimated in the tank for 24 hours before the experimentation time in Aquatic Ecology Laboratory, Institut Teknologi Bandung (ITB). V. harveyi culture was obtained from Institut Pertanian Bogor (IPB) collection, whereas the two probiotic were isolated and selected from Situbondo hatchery, East Java. Optimum cell number of H. aquamarina is $10^{6} \mathrm{CFU} \cdot \mathrm{mL}^{-1}$ and $10^{5}$ CFU.mL $L^{-1}$ for $S$. algae [12]. Optimum cell number of $V$. harveyi to cause shrimp infection is $10^{4} \mathrm{CFU} \cdot \mathrm{mL}^{-1}$ similar to [9]. Bacteria were used at 24 hours inoculum age by inoculum number as $0.1 \%{\mathrm{v} . \mathrm{v}^{-1}}^{-}$.

Pathogenicity test of probiotic to PL-4 white shrimp: $H$. aquamarina and S. algae were tested for their Pathogenicity potential to PL-4 white shrimp culture. Pathogenicity test used four chemical glasses (2L), each of them was contained 1.5 liter sea water. As $0.1 \% \mathrm{v} . \mathrm{v}$ ${ }^{1}$ of each bacteria was used [(K) no addition of bacteria; (P8) addition of H. aquamarina; (P9) addition of S. algae; and (V) addition of V. harveyi] in cell optical density $10^{6} \mathrm{CFU} \cdot \mathrm{mL}^{-1}, 10^{5} \mathrm{CFU} \cdot \mathrm{mL}^{-1}$ and $10^{4} \mathrm{CFU} \cdot \mathrm{mL}^{-1}$ for $H$. aquamarina, S. algae and $V$. harveyi respectively. Age of these three inoculums bacteria were 24 hours. In this test, 50 PL- 4 white shrimp were added to each test group. Pathogenicity test was done for 12 days. Remain number of white shrimp in each test group was calculated at the end of culture period to know the survival rate.

\section{Application of probiotic bacteria in PL-4 white shrimp culture}

Experimental set up: 10L sterilized sea water with 30 ppt salinity was stocked per tank which the bottom has been covered by sterilized bicarbonate stone for buffering. Aeration line was settled then connected to aeration pump (Figure 1) and each tank with aeration rate at $200 \mathrm{~mL} \cdot \mathrm{min}^{-1}$.

Probiotic bacteria was activated for 24 hours, and added to the culture based on treatment group (Table 1 ) as $0.1 \% \mathrm{v} . \mathrm{v}^{-1}$ for concentration and optical density $10^{6}$ CFU.mL ${ }^{-1}$ for $H$. aquamarina, $10^{5} \mathrm{CFU} \cdot \mathrm{mL}^{-1}$ fo S. algae. Bacteri $V$. harveyi $\left(0.1 \% \mathrm{v}^{-1}\right)$ was added to the culture based on treatment after 24 hours from addition of probiotic. Then, PL-4 was added to the culture by stocking density 330 individuals/tank. Experiment was conducted for 12 days in $26 \pm 2^{\circ} \mathrm{C}$ temperature, by

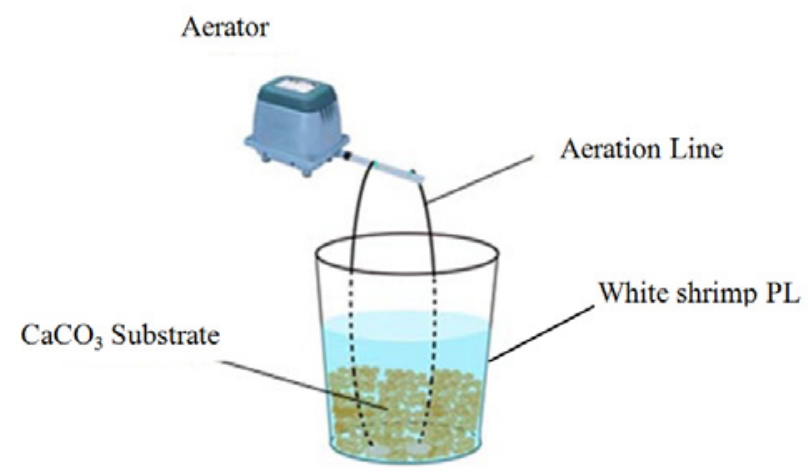

Figure 1: Installation System of $H$. aquamarina and $S$. algae application to against $V$. harveyi in L. vannamei Culture [13].

\begin{tabular}{|c|c|}
\hline Group & Bacteria Inoculum Addition \\
\hline K & No bacteria added \\
\hline KP8 & Added $0.1 \%$ v.v $^{-1} H$. Aquamarina \\
\hline KP9 & Added $0.1 \%$ v. $v^{-1}$ S. algae \\
\hline KV & Added $0.1 \%$ v. $\mathrm{v}^{-1} \mathrm{~V}$. harveyi \\
\hline KC & Added $0.1 \%$ v.v $^{-1} \mathrm{H}$. aquamarina and S. Algae \\
\hline P8 & Added $0.1 \%$ v. $v^{-1} H$. aquamarina and $V$. harveyi \\
\hline P9 & Added $0.1 \%$ v. $v^{-1}$ S. algae and V. harveyi \\
\hline PC & Added $0.1 \%$ v. $v^{-1} H$. aquamarina, S. algae and $V$. harveyi \\
\hline
\end{tabular}

Table 1: Treatments of pathogenesis probiotics bacteria test againts Vibrio harveyi in white shrimp culture.

three repetitions for each treatment. Zero water discharged method was used in this experiment by adding $\mathrm{CaCO}_{3}$ stone on each bottom tank as culture substrate [13]. The culture was fed with microalgae (Chaetoceros sp.) and sterilized Artemia sp. larvae. The amount of feed was adapted to the number of white shrimp PL stocking density. Microalgae were delivered manually two times a day at $09.00 \mathrm{am}$ and $03.00 \mathrm{pm}$, and Artemia sp. was delivered three times a day at $08.00 \mathrm{am}$, $12.00 \mathrm{pm}$, and $08.00 \mathrm{pm}$.

Observation was consist of white shrimp survival in the end of culture period, length and weight of white shrimp at the beginning and the end of the culture, water quality parameter measurements (temperature, salinity, $\mathrm{DO}, \mathrm{pH}$, ammonia, nitrite, and nitrate), bacterial community counting, bacterial identification and bacteria population dynamic during culture.

Water quality parameter: Several water quality parameters, i.e., temperature, salinity, $\mathrm{pH}$ level, and dissolved oxygen (DO) were measured every day, while ammonia, nitrite, and nitrate concentrations were measured every two days. Temperature was measured using thermometer, DO was measured using calibrated DO meter YSI Type $51 \mathrm{~B}, \mathrm{pH}$ level was measured using $\mathrm{pH}$ meter OAKTON waterproof Type PC10, while salinity was measured using refractometer. The ammonia, nitrate and nitrite concentration was measured using measurement kit and HACH Spectrophotometer by following the Nessler-, Diazotation-, and Nitrate $\mathrm{HCl}$ method at the wavelengths of 425, 371, 275 and 220 $\mathrm{nm}$ respectively.

Zootechnical parameters of white shrimp: Survival rate of $L$. vannamei was calculated at the end of culture period by counting the number of remaining shrimp as compared to the initial stock number. The survival rate of the PL was conducted by using the following equation [13]:

\section{$\mathrm{SR}=\mathrm{Nt} / \mathrm{No} \times 100 \%$}

Where:

\section{$\mathrm{SR}=$ Survival Rate}

No=Initial shrimp number

$\mathrm{Nt}=$ Final shmrip number

Mean individual body weight and length of shrimp postlarvae were recorded for $20 \%$ of the population in each treatment at the end of culture period.

Bacterial sampling: Microbiological analyzes performed by sampling $10 \mathrm{~mL}$ water from each rearing tank and sampling shrimp for bacterial intestine analysis. Serial dilution $\left(10^{-1}, 10^{-2}, 10^{-3}, 10^{-4}\right.$ etc.) were prepared in sterile saline solution $\mathrm{NaCl}(1.5 \%)$ from the homogenized samples and $0.1 \mathrm{~mL}$ was plated in duplicate on NA (nutrient agar) and TCBS (Thio agar. The plates were incubated at $25^{\circ} \mathrm{C}$ and bacterial 
Citation: Suantika G, Aditiawati P, Astuti DI, Khotimah ZF (2013) The Use of Indigenous Probiotic Halomonas aquamarina and Shewanella algae for White Shrimp (Litopenaeus vannamei Boone) Hatchery Productivity in Zero Water Discharge System. J Aquac Res Development 4: 194 doi:10.4172/2155-9546.1000194

Page 3 of 8

counts performed after $24-48$ hours. Number of bacteria was resulted of number colony counted on Petri dish multiply to dilution factor [14].

Bacterial identification: Bacterial identification was done by checking colony morphology of bacteria, Gram test, and 17 biochemical activity tests (carbohidrate fermentation, lipid hydrolysis, starch hydrolysis, casein hydrolysis, urease, TSI, IMViC, MRVP, gelatine, catalase, nitrate reduction, and $\mathrm{H} 2 \mathrm{~S}$ ) to figure out bacteria diversity in the water during culture period [14]. The result of determination bacterial properties was checked using "Bergey's Mannual of Determinative Bacteriology".

Statistical analyses: All data were statistically treated using oneway ANOVA. Significant differences among means $(\mathrm{p}<0.05)$ were tested by Duncan's multiple range test.

\section{Results and Discussion}

\section{Pathogenicity test of probiotic bacteria to white shrimp postlarvae}

Pathogenicity test was done to check whether H. aquamarina and $S$. algae give negative effect to white shrimp PL culture or not. The result of pathogenicity is represented in white shrimp survival rate (Figure 2). The result shows that the probiotic bacteria were harmless to shrimp postlarvae and the highest survival rate percentation was in the group addition of $H$. aquamarina probiotic (98\%), and followed by control (96\%), addition of S. algae (84\%) and the lowest was result of addition $V$. harveyi (54\%). Addition $H$. aquamarina gave better survival rate than addition of $S$. algae. This implied that $H$. aquamarina gave better effect as probiotic than $S$. algae, which was also proven by inhibition zone diameter produced by each probiotic from Kirby Baueur method [12]. Result of addition $V$. harveyi shows that this bacteria give pathogenicity effect to the white shrimp postlarvae, similar to result of former research [11].

\section{Application of probiotic bacteria in PL-4 white shrimp culture}

Water quality parameter: Water quality is important factor in white shrimp culture, since water is its life habitat so they can effects each other. Water quality needs to be observed because low water quality will facilitates pathogenic bacteria activity to infect shrimp in the culture and resulted in lower growth and survival rate [15]. Result of water quality parameter measurement including temperature, salinity, $\mathrm{DO}, \mathrm{pH}$, and level of ammonia, nitrite, nitrate is presented in Table 2 .

Temperature: Water temperature is one factor that affects shrimp metabolism rate, food and oxygen consumption rate, ammonium excretion rate, and growth rate. The increase of temperature trigger the

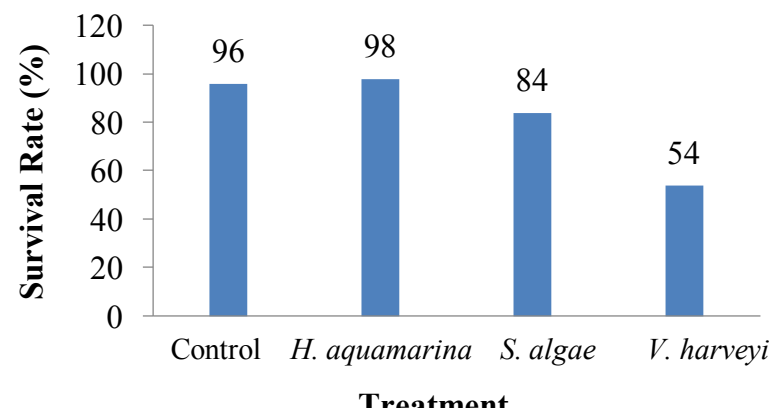

Figure 2: Survival rate of white shrimp PL obtained from pathogenicity test.

\begin{tabular}{|l|c|c|}
\hline Parameters & Optimum Range & Culture Range \\
\hline Temperature $\left({ }^{\circ} \mathrm{C}\right)$ & $28-32$ & $26-28$ \\
\hline Salinity $(\mathrm{ppt})$ & $0.5-35$ & $26-30$ \\
\hline $\mathrm{DO}\left(\mathrm{mg} \cdot \mathrm{L}^{-1}\right)$ & $5.0-9.0$ & $5.7-6.4$ \\
\hline $\mathrm{pH}$ & $7.0-8.3$ & $7.5-8.5$ \\
\hline Ammonia $\left(\mathrm{mg} \cdot \mathrm{L}^{-1}\right)$ & $<0.03$ & $0.1-0.5$ \\
\hline Nitrite $\left(\mathrm{mg} \cdot \mathrm{L}^{-1}\right)$ & $<1.0$ & $0.02-0.25$ \\
\hline Nitrate $\left(\mathrm{mg} \cdot \mathrm{L}^{-1}\right)$ & $<60$ & $5-40$ \\
\hline
\end{tabular}

Table 2: Water quality parameters of white shimp PL culture in different treatment during 12 days culture period.

metabolism rising to the maximum rate [16]. Based on the result, there was no fluctuative changes in water temperature. Water temperature during culture period always within range $26-28^{\circ} \mathrm{C}$. These were still in the tolerance range of temperature requirement of shrimp to survive $\left(24-32^{\circ} \mathrm{C}\right)$. Statistical analysis shows that there was no temperature significant difference of all of culture treatment during culture period $(p>0.05)$. L. vannamei is included to poikilothermic organism, therefore the body temperature is influenced by ambient temperature. White shrimp has wide tolerance range of temperature, with maximum temperature achieved within range $28-32^{\circ} \mathrm{C}$. Water temperature less than $15^{\circ} \mathrm{C}$ and more than $35^{\circ} \mathrm{C}$ (long term) or $45^{\circ} \mathrm{C}$ (short term), may trigger shrimp mortality [17].

Salinity: Result of this research shows that salinity during culture period were not extremely change. Range of culture salinity is around 26-30 ppt, and it is still in salinity requirement tolerance range for white shrimp [16]. Statistical analysis shows that there was no salinity significant difference of all of culture treatment during culture period $(p>0.05)$.

Based on tolerance range for water salinity, aquatic organism classified into two groups, stenohaline and eurihaline. Stenohaline is organisme which is adaptable to narrow tolerance range environment salinity, and eurihaline is organisme which is adaptable to dynamically changing salinity (wide tolerance range). White shrimp is classified as eurihaline organisme that adaptable to fluctuative salinity [16]. Penaeid shrimp has different salinity range during life time cycle. Larvae and juvenille can adapt to survive even in the high salinity environment, range 1-40 ppt. Adult shrimp needs salinity $28-35 \mathrm{ppt}$ to active reproduce offspring. Shrimp has good osmoregulation capability even life in low salinity. This capability developed gradually since postlarvae [17].

Dissolved oxygen (DO): Oxygen is physiologically needed in the cell for carbohidrate oxidation. In the aquatic environment, DO level is important factor not only for aquatic organism respiration, but also important to maintain chemical environment and water hygiene for organism. Two kind of biologic factors that effect DO level are respiration and photosynthesis [18].

Table 2 shows that DO level of this research were between 5.7-64 mg. $\mathrm{L}^{-1}$. As of DO level of this culture still in the tolerance range of shrimp, 5-9 mg.L $\mathrm{L}^{-1}$ [16]. DO level may affects food metabolisme rate, growth rate, and food convertion rate. Decreasing of DO will lead to decreasing of food metabolism rate, growth rate, and food convertion rate. DO less than $1.5 \mathrm{mg} . \mathrm{L}^{-1}$ for long time can cause shrimp mortality [17]. Statistical analysis shows that there was no DO level significant difference of all of culture treatment during culture period $(p>0.05)$.

Acidity level (pH): $\mathrm{pH}$ level is a negative log of hydrogen ion concentration in the water. $\mathrm{pH}$ is affected by respiration proccess, which can make the $\mathrm{pH}$ level decrease. $\mathrm{CO}_{2}$ in the water dissolved to 
Citation: Suantika G, Aditiawati P, Astuti DI, Khotimah ZF (2013) The Use of Indigenous Probiotic Halomonas aquamarina and Shewanella algae for White Shrimp (Litopenaeus vannamei Boone) Hatchery Productivity in Zero Water Discharge System. J Aquac Res Development 4: 194 doi:10.4172/2155-9546.1000194

Page 4 of 8

form $\mathrm{H}_{2} \mathrm{CO}_{3}$. $\mathrm{pH}$ level less than 6.5 or more than 10 will be dangerous for shrimp gills and affect in decreasing shrimp growth rate. $\mathrm{pH}$ range of water culture was 7.5-8.5 and still in the tolerance range $\mathrm{pH}$ requirement, 7-9. Statistical analysis shows that there was no salinity significant difference of all of culture treatment during culture period $(p>0.05)$. $\mathrm{pH}$ level is affected by respiration which can makes $\mathrm{pH}$ decreases, and photosynthesis which can makes $\mathrm{pH}$ increases. If $\mathrm{pH}$ level is too high of low, cultured white shrimp will be influenced. $\mathrm{pH}$ $<6.5$ or $>10$ is harmful for gill and will reduces shrimp growth rate [16].

One of the main problem source related to disease in shrimp culture is deterioration of water quality. Zero water discharge applied in this research contributes in maintaining water quality parameter within tolerance level of white shrimp PL culture. Addition of $\mathrm{CaCO}_{3}$ stone on the culture tank bottom worked as culture substrate which could help in buffering the $\mathrm{pH}$ stability [19].

Ammonia: Ammonia is one of nitrogen compound in the water culture. One of ammonia source is shrimp feed. Feed protein which have been consumed are assimilated and excreted through feces. Twenty percent of food protein enter the culture system and converted to ammonia. Ammonia excreted through gills and dissolved in water. Beside feed, ammonia is also produced from organic matter decomposition by heterotroph bacteria [17].

Ammonia concentration during culture period ranged from 0.1 to $0.5 \mathrm{mg} . \mathrm{L}^{-1}$ (Table 2). It shows that ammonia concentration in culture exceeded maximu concentration of shrimp water culture, $0.1 \mathrm{mg} \cdot \mathrm{L}^{-1}$. Particularly this high ammonia concentration did not affect white shrimp life significantly. It was caused by the water $\mathrm{pH}$ still optimum. Statistical analysis shows that there was no significantly difference of ammonia concentration for every treatment.

In the water system, there are two kinds of ammonium compound. Unionized form as ammonia and ionized form as ammonium. Total nitrogen ammonium of water system is a combination of both ammonium form. Ammonia concentration in the water is affected by $\mathrm{pH}$ level and water temperature. At $\mathrm{pH}$ level of 7 , most ammonium total are in the unionized form. The increase of $\mathrm{pH}$ level and temperature trigger the raising of unionized ammonium level. $\mathrm{pH}$ level 9 show that $50 \%$ of total ammonium are in the unionized form [17]. Unionized ammonium form is toxic compound for shrimp, but ionized form is intoxic. $\mathrm{LC}_{50}$ level of unionized ammonium form for juvenille shrimp is $1.26 \mathrm{mg} \mathrm{NH} 3-\mathrm{N} . \mathrm{L}^{-1}$. Unionized ammonium more than $0.1 \mathrm{mg} . \mathrm{L}^{-1}$ is still safe and does not trigger shrimp mortality. Unionized ammonium more than $0.3 \mathrm{mg} \cdot \mathrm{L}^{-1}$ causing non-lethal effect such as low growth rate, increase of food conversion, decrease of low DO tolerance and disease resistancy [16].

Nitrite: Result of nitrite measurement during 12 days culture ranged from $0.02-0.25 \mathrm{mg} . \mathrm{L}^{-1}$ (Table 2). This nitrite concentration is still under the maximum concentration which allowed in the shrimp water culture. Maximum nitrite allowed is $1 \mathrm{mg} . \mathrm{L}^{-1}$ [2]. Result of statistical analysis shows that nitrite concentration of each group treatment was not significantly different.

Nitrite is also one of toxic compound for shrimp at the certain level. $\mathrm{LC}_{50}$ of nitrite concentration for shrimp is $13.6 \mathrm{mg} . \mathrm{L}^{-1}$ in the 96 hours, with safe level recommendation at $1.36 \mathrm{mg} . \mathrm{L}^{-1}$ [17]. High nitrite concentration affects oxygen uptake in the red blood cell haemoglobine, and cause asphyxiation. Nitrite is a product from nitrification process by Nitrosomonas bacteria. Nitrite can be accumulated in the water when nitrification rate is low. Nitrite toxicity for shrimp is affected by shrimp life cycle and water salinity [17].
Nitrate: Actually nitrate compound is not toxic in the shrimp culture. Based on that result, nitrate concentration was ranged 5-40 mg. $\mathrm{L}^{-1}$. These concentration is still below maximum nitrate concentration for shrimp culture, that is $60 \mathrm{mg} . \mathrm{L}^{-1}$ [19]. Based on statistical analysis, there was no significantly difference between nitrate concentration of each groups treatment $(p>0.05)$. Nitrate concentration from the beginning to the end culture period increase for each of groups treatment. It may be indicates that nitrite in the water system has been converted to nitrate form in the nitrification process. Nitrite is unstable compound with the oxygene level. Because this unstability, nitrite is easy to converted to form nitrate by bacteria [17]. It seems that nitrite concentration in the water system particularly at low level, but nitrate concentration is at high level.

\section{White shrimp PL survival rate and growth}

Survival rate of white shrimp larvae was also determined to know the effect of addition $H$. aquamarina and $S$. algae to white shrimp culture infected by $V$. harveyi. Figure 3 shows survival rate of white shrimp PL in the antagonist effect of probiotic bacteria to the V. harveyi. The highest survival rate was in the addition of $H$. aquamarina to the culture (KP8) followed by addition of S. algae (KP9), H. aquamarina-S. algae (KC), S. algae-V. harveyi (P9), $H$. aquamarina-S. algae-V. harveyi (PC), H. aquamarina- $V$. harveyi (P8), and control (K). The lowest survival rate obtained from addition of $V$. harveyi $(\mathrm{KV})$.

Statistical analysis shows that there was significant difference for the result of survival rate on addition probiotic treatment with no probiotic. Survival rate of $\mathrm{K}$ was different significantly with others treatment, where the survival rate was higher than KV and lower than other six treatment groups. KV also has significant difference with other groups treatment, it shows that addition of patoghenic bacteria, $V$. harveyi, in the culture give lower white shrimp survival rate significantly $(p<0.05)$. On the other hand, addition probiotics to the culture help decrease infection of $V$. harveyi.

Addition probiotic to white shrimp PL culture as a single inoculum was not significantly different with addition of mix culture of both probiotics. However, addition of S. algae as single probiotic (P9) gave higher survival rate and different significantly with $H$. aquamarina treatment (P8). There are some factors that affect lower survival rate

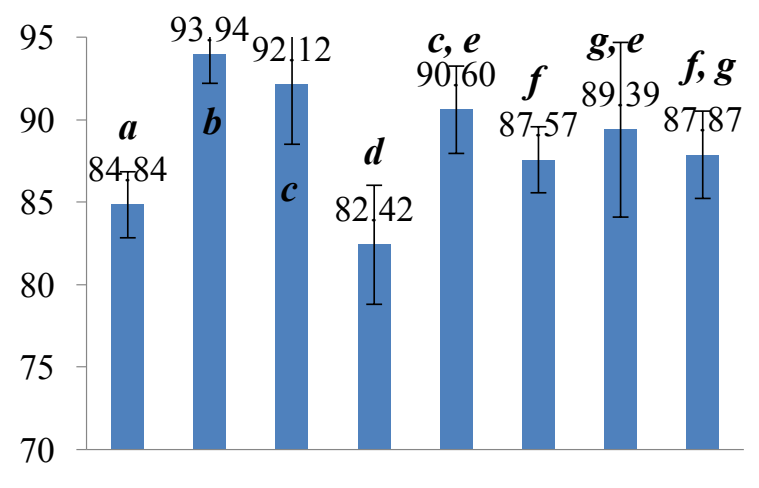

$\begin{array}{llllllll}\text { K } & \text { KP8 } & \text { KP9 } & \text { KV } & \text { KC } & \text { P8 } & \text { P9 } & \text { PC }\end{array}$

\section{Treatment}

Figure 3: White shrimp PL survival rate at the end of culture period of probiotic against $V$. harveyi test. 
Citation: Suantika G, Aditiawati P, Astuti DI, Khotimah ZF (2013) The Use of Indigenous Probiotic Halomonas aquamarina and Shewanella algae for White Shrimp (Litopenaeus vannamei Boone) Hatchery Productivity in Zero Water Discharge System. J Aquac Res Development 4: 194 doi:10.4172/2155-9546.1000194

Page 5 of 8

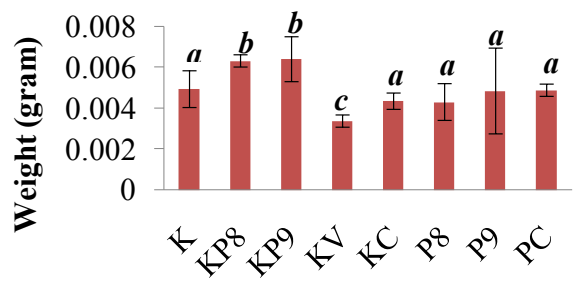

Treatment

Figure 4: Increase of white shrimp PL weight at the end of culture period.

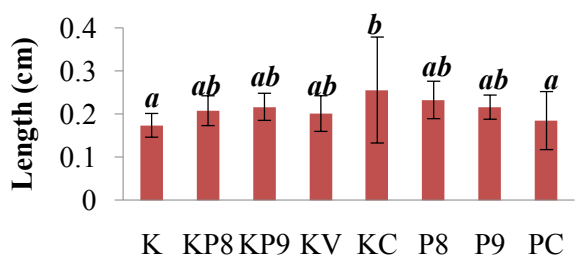

Treatments

Figure 5: Increase of white shrimp length at the end of culture period.

\begin{tabular}{|l|l|}
\hline Species & Name \\
\hline Species 1 & H. aquamarina \\
\hline Species 2 & S. algae \\
\hline Species 3 & V. harveyi \\
\hline Species 4 & Spingobacterium sp. \\
\hline Species 5 & Bacillus sp. \\
\hline Species 6 & Micrococcus sp. \\
\hline Species 7 & Pseudomonas sp. \\
\hline Species 8 & Alcaligenes sp. \\
\hline
\end{tabular}

Table 3: Species of identified bacteria during white shrimp culture period.

due to application of mix probiotic culture: different of probiotic growth characteristic, uptake nutrient ability, doubling time, space competition and communication [20].

Growth of white shrimp postlarvae was observed from individual average of body weight and length that measured at the beginning and the end of the culture period. In general, the average of body weight and lenght of individual postlarvae had increased. From the collected data (Figure 4), the highest body weight acquired by KP9, KP8, K, PC, P9, $\mathrm{KC}, \mathrm{P} 8$, and the last is $\mathrm{KV}$. The result of statistical analyses indicating that growth of body weight is significantly different for group $\mathrm{KV}$, it indicated that addition of $V$. harveyi to the culture provided negative effects shown by the lowest final body weight. Over all, there was no significantly differences of final body weight for each group. The addition of probiotic to challenge $V$. harveyi did not give a different higher final body weight significantly.

Figure 5 shows data of white shrimp PL body length. The highest body length increase acquired by KC, followed by P8, KP9, P9, KP8, $\mathrm{KV}, \mathrm{PC}$, and the last is $\mathrm{K}$. Based on statistical analyses, there is no any significantly differences of body length for all of the group $(p>0.05)$. It indicates that addition of probiotic did not give any effect to body length. However, there were some significant differences of body weight increase for some treatment group. KV was different significantly with other groups, by the lowest body weight. And addition of probiotic (KP8 and KP9) were different significantly with other groups.

Bacteria identification: Bacteria which were found both in water and shrimp's intestine sample were identified hrough biochemistry test method (Table 3). Generally, H. aquamarina and S. algae were found in all of culture treatment group. It shows that these two probiotics are indigenous bacteria in white shrimp culture.

\section{Population of H. aquamarina, S. algae and V. harveyi during culture}

Bacteria population in culture water: Bacteria population checked from $1 \mathrm{~mL}$ sample of $L$. vannamei culture water shows that there were various bacterial species found in each treatment as shown in Figure 6. Probiotic $H$. aquamarina and $S$. algae, as well as the pathogen, $V$. harveyi could be found in all treatment with different level of cell number. This condition means all bacteria were actually also indigenous bacteria that originally habitant seawater or sea culture.

Treatment $\mathrm{K}$ with no isolate was added, still shown presence of both probiotics and $V$. harveyi. It shows that these three bacteria are indigenous bacteria in the white shrimp culture. H. aquamarina, $S$. algae and $V$. harveyi were found since the beginning of culture period. $V$. harveyi could grow in water culture even there was inhibition by the two probiotics. Number of $V$. harveyi was reached $10^{4} \mathrm{CFU} \cdot \mathrm{mL}^{-1}$ since day 2. In the middle of culture periode, $V$. harveyi was increased and then followed by decrease that resulted of H. aquamarina and S. algae activity interaction
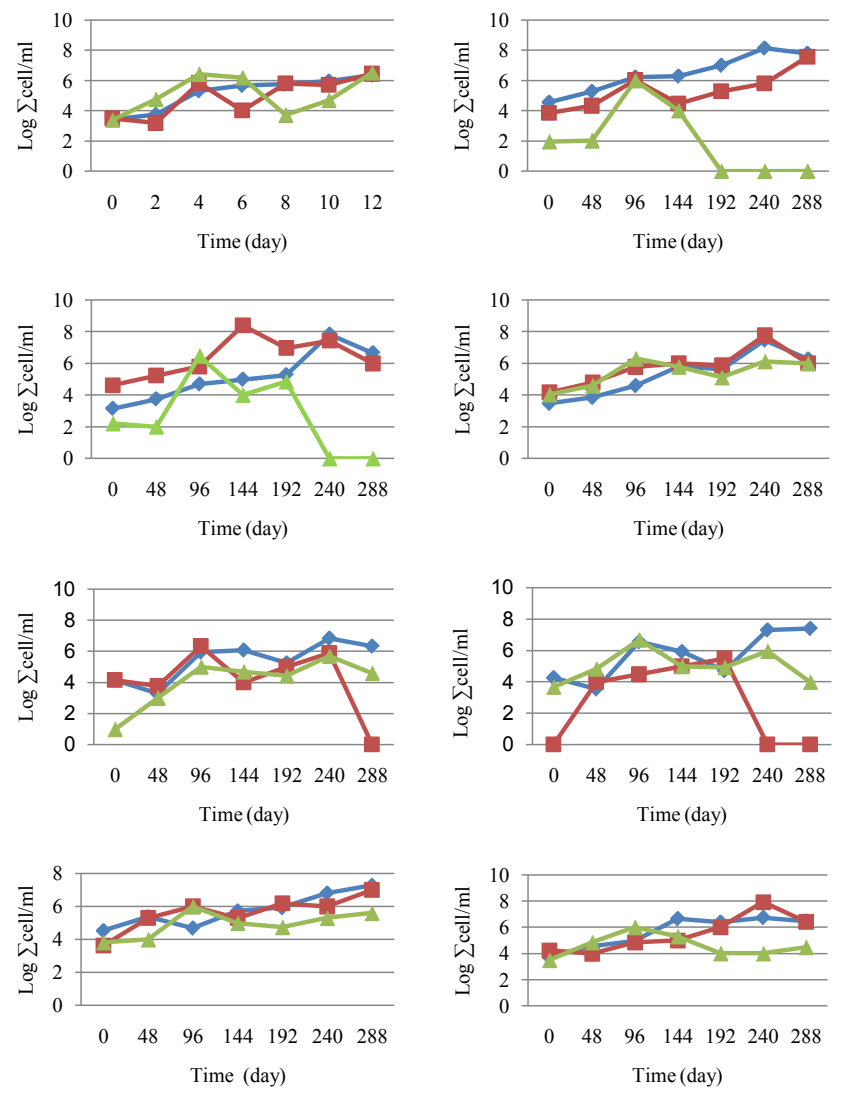

Figure 6: Bacteria Population Percentage from Water Sample of White Shrimp Culture $(\multimap$. H. aquamarina, $\rightarrow$ S. algae, $\longleftarrow$ V. harveyi). 
Citation: Suantika G, Aditiawati P, Astuti DI, Khotimah ZF (2013) The Use of Indigenous Probiotic Halomonas aquamarina and Shewanella algae for White Shrimp (Litopenaeus vannamei Boone) Hatchery Productivity in Zero Water Discharge System. J Aquac Res Development 4: 194 doi:10.4172/2155-9546.1000194

Page 6 of 8
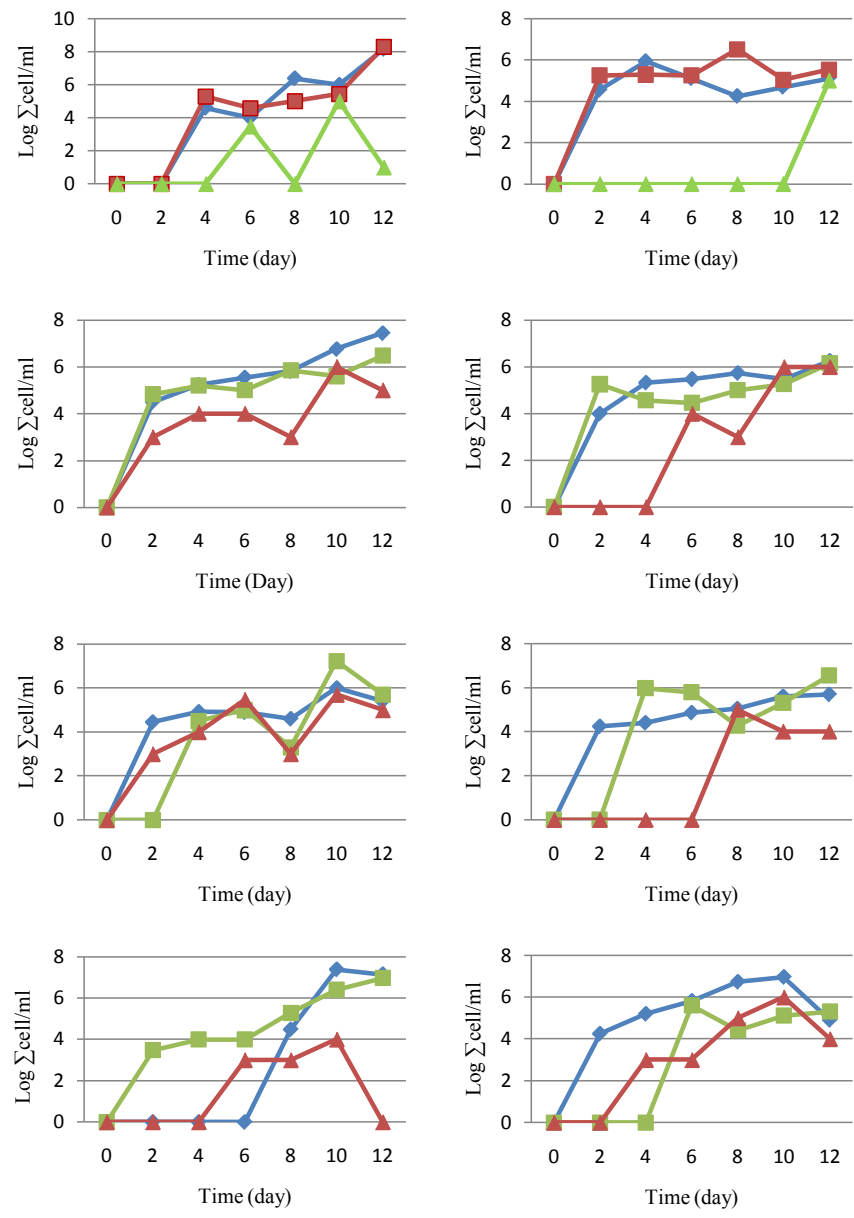

Figure 7: Bacteria Population Percentage from White Shrimp Intestine $(\because-$ H. aquamarina, $\rightarrow$ S. algae, $\rightarrow$ V. harveyi $)$

Treatment KP8 with adition of H. aquamarina, makes this bacteria able to dominate during white shrimp culture period. Growth of $H$. aquamarina tent to increase since the beginning until the end of culture period. S. algae were not added to the culture, still shown its existence and growth, which further indicates that this bacteria is indigene bacteria in white shrimp culture. $V$. harveyi was found in the culture since the beginning, but then was not found any more since the middle to the end of culture period. This possibly was a result of $H$. aquamarina and $S$. algae activity that existed and continued to dominated bacteria population in the culture. These results were also consistent with the result of survival rate, which was the highest, due to antagonistic activity of probiotics against $V$. harveyi.

In KP9 treatment group, S. algae were added to white shrimp culture. Based on the result, the addition of $S$. algae to the culture made these bacteria dominated at the beginning of culture period and then continues to grow. In this group, $H$. aquamarina and $V$. harveyi were also found. Similar with $S$. algae, $H$. aquamarina was grown during culture period. The growth of these two probiotics made growth of $V$. harveyi became decreased and then not found in the culture. The result of both probiotics activity in inhibiting $V$. harveyi was consistent with result of survival rate.

In $\mathrm{KV}$ treatment group, $V$. harveyi was added to white shrimp culture. Based on the result, addition of $V$. harveyi to the culture made this bacteria population remain high during culture period, although probiotic $H$. aquamarina and $S$. algae also exsisted. The existence of these two probiotics did not give significant inhibition to $V$. harveyi growth in this group treatment. $V$. harveyi has achieved a high number since the biginning of culture period, which may support it to become pathogenic bacteria. V. harveyi infected white shrimp, so it survival rate became the lowest.

In KC treatment group, $H$. aquamarina and $S$. algae were added to white shrimp culture. Based on the result, addition of both probiotics as mix culture made their number become stable at the beginning of culture period, whereas $V$. harveyi number was low. During culture period, growth of $V$. harveyi was increased until the end of period. It shows that addition of probiotic as mix culture decreased both probiotics activity in against $V$. harveyi. In other word, growth type of both probiotics was neither symbiotic nor synergic. It was consistent with white shrimp survival rate, which shown that survival rate was lower than application of probiotic as single culture (KP8 and KP9).

In P8 treatment group, $H$. aquamarina and $V$. harveyi were added to the culture. $H$. aquamarina dominated bacteria population of this treatment group during culture period. Compared with the control (K) and addition of $H$. aquamarina (KP8), the growth of $H$. aquamarina in P8 was not as optimal as KP8. This was the result of competition between $H$. aquamarina and $V$. harveyi, in term of nutrient and space. This competition also affected inhibitory activity of $H$. aquamarina against $V$. harveyi, shown by lower survival rate obtained.

In $\mathrm{P} 9$ treatment group, $S$. algae and $V$. harveyi were added to the culture. In this treatment group, each of H. aquamrina, S. algae and $V$. harveyi has balanced growth during culture period. Even $H$. aquamarina was not added to the culture, it was still exsisted during culture. The addition of $V$. harveyi increased its ability to infect white shrimp, eventhough both probiotics existed in the culture. It is consistent with result of survival rate, when $V$. harveyi was added to the culture, survival rate became lower.

In PC treatment group, $H$. aquamarina, S. algae and $V$. harveyi were added to the culture. In the graph, shown that each bacteria was fluctuated during culture period. The number of $V$. harveyi decreased at the end of culture, as a result of probiotics inhibition activity.

Bacteria population in L. vannamei intestine: Bacteria found in L. vannamei intestine samples are mostly same with those found in culture water (Figure 7), except one different species assumed to be normal microflora of $L$. vannamei, Micrococcus sp. Sample of crushed intestine was diluted in $0.85 \% \mathrm{NaCl}$ solution is checked, it gave varies result among treatments. Result of treatment $\mathrm{K}$ demonstrates that both probiotics, $H$. aquamarina and $S$. algae, and $V$. harveyi were consumed by shrimp culture. Micrococcus sp. is found in this culture. Dynamic growth of each culture was shown, $H$. aquamarina was still increasing by days.

In treatment KP8, both probiotics could be found since day 2, each species fluctuated and tend to be decreasing. V. harveyi found only in the last day, dominating bacteria in this culture was Bacillus sp, which also classified as normal microflora of shrimp culture. Whereas in treatment KP9 $V$. harveyi has already found since the first sampling, it could not be reduced completely that it was still found in day 12 . It shows that adding only $S$. algae to the culture is not an effective preventive method against pathogen.

Addition of pathogen isolate to the culture affects not only microbial diversity in water, but also in the shrimp's intestine. In treatment $\mathrm{KV}$, 
Citation: Suantika G, Aditiawati P, Astuti DI, Khotimah ZF (2013) The Use of Indigenous Probiotic Halomonas aquamarina and Shewanella algae for White Shrimp (Litopenaeus vannamei Boone) Hatchery Productivity in Zero Water Discharge System. J Aquac Res Development 4: 194 doi:10.4172/2155-9546.1000194

Page 7 of 8

colonies of this pathogen found in a big number since day 6 , it reaches the highest level in the last sampling day. Comparing to microbial diversity chart in culture water, it figures that in the middle of culture period where $V$. harveyi seemed to be highly reduced, it was actually consumed and penetrate L. vannamei intestine. Shrimp cultures have been attacked by $V$. harveyi colonization resulting a low percentage of survival rate.

Growth rate of both H. aquamarina and S. algae in treatment $\mathrm{KC}$ shows an antagonistic activity of both culture. V. harveyi was found since day 0 to day 12 , means that if there was any inhibition action in shrimp's intestine, it could not work properly to inhibit this pathogen to grow continuously. Micrococcus sp could also grow well in the culture. It is the same as treatment 8 , cell number of $H$. aquamarina was becoming more dominant.

Treatment P8 and P9 pictures the ability of $V$. harveyi to habitant $L$. vannamei intestine in the middle of culture period, around day 6 and 8. This condition shows that inhibition mechanism performed by $H$. aquamarina in secreting bacteriosin, which considered more effective than S. algae, works better in the water rather than inside the shrimp intestine.

Based on the whole result of bacterial activity and survival rate of white shrimp PL, H. aquamarina and $S$. algae have the ability to inhibit or reduce pathogenicity effect of $V$. harveyi in white shrimp culture. Although this research was not able to analyse the exact mode of action of each probiotic, there are some previous research which show several mechanisms of bacteria from Genus Halomonas and Shewanella as probiotic. As it stated by Bitzer et al. [21] that halophilic bacteria from Genus Halomonas are able to produce antibiotic aminophenoxazinones which has been proven in inhibiting growth of gram negative bacteria, E. coli. Based on these ability, it is likely that Halomonas also able to inhibit other Gram negative bacteria such as Vibrio harveyi. Even so, further research is needed to prove the hypothesis. Other research stated that $H$. aquamarina has the ability to produce siderophore molecule, aquachelins, which plays a role to bind, as a solvent, and transporter of $\mathrm{Fe}^{3+}$ complex from aquatic environment in to cell. This ability contribute in helping white shrimp to maintain important nutrition in the body [22]. In addition, $H$. aquamarina plays a role as non-pathogen bacteria which help reduce pathogen bacteria infection in shrimp intestine by producing exoenzyme and organic compound (compatible solutes) to control defense of intestinal mucus $[23,24]$.

On the other hand, S. algae as probiotic produces biofilm which help attachment and colonization on white shrimp intestine, produce bacteriocin, and also produces pigmen compound (pyomelanin) which protect this bacteria from hydrolytic enzyme in aquatic environment. Pyomelanin also known has important role in biogeochemical cycle of Fe in aquatic environment [25-27].

\section{Conclusion}

During culture period, water quality parameters consisting of temperature, salinity, $\mathrm{pH}$ level, and dissolved oxygen (DO), ammonia, nitrite, and nitrate concentrations mostly tended to be stable and there were no significant difference by days. The lowest survival rate given by treatment 4 with addition of only $V$. harveyi isolate. Although both probiotics perform an inhibitory activity to challenge $V$. harveyi, $H$. aquamarina was dominating and found to be more effective than $S$. algae. Thus, single culture of $H$. aquamarine could perform better result to maintain L. vannamei postlarvae culture rather than mixed culture, since the growth rate of both probiotics did not show neither symbiotic or synergic activity.

\section{Acknowledgment}

We would like to thank DIPA for the financial support.

\section{References}

1. http://en.engormix.com/MA-aquaculture/healt/articles/bioremediationadvanced-strategy-restore_1194.htm.

2. Farfanzar $A(2006)$ The use of probiotics in shrimp aquaculture. FEMS Immuno Med Microbiol 48: 149-158.

3. http://www.agnet.org/library/bc/55008/

4. Lidder P, Sonnino A (2012) Biotechnologies for the management of genetic resources for food and agriculture. Adv Genet 78: 1-167.

5. Wyban J (2009) World Shrimp Farming Revolution: Industry Impact of Domestication, Breeding and Widespread Use of Specific Pathogen Free Penaeus Vannamei. White Shrimp Domestication and Breeding.

6. Ekmaharaj, Siri (2008) Review of Shrimp Farming in Southeast Asia and China SEAFDEC Special Publication "Fish For the People" Vol: 4

7. Aung O, Kyi A, Yu SS (2008) Assessment of Beneficial Bacteria (Probiotic) as Biological Control in Giant Freshwater Prawn (Macrobrachium Rosenbergii) Hatchery System, GMSARN International Conference on Sustainable Development: Issues and Prospects for the GMS.

8. Moriarty DJW (1999) Disease Control in Shrimp Aquaculture with Probiotic Bacteria. Proceedings of the 8th International Symposium on Microbial Ecology, pp 237-243. Atlantic Canada Society for Microbial Ecology, Halifax, Canada.

9. Robertson PAW, Calderon J, Carrera L, Stark JR, Zherdmant M, et al. (1998) Experimental Vibrio harveyi infections in Penaeus vannamei larvae. Dis Aquat Org 32: 151-155.

10. Leungprasert S, Chanakul P (2010) The Reuse of Shrimp Culture Wastewater Treated by Nitrification and Denitrification Processes. International Journal of Environmental Science and Development 1: 371-377.

11. Baliao DD, Tookwinas S (2002) Best management practices for a mangrovefriendly shrimp farming. Filipina: Aquaculture Department, Southeast Asian Fisheries Development Center.

12. Suantika G, Aditiawaty P, Astuti DI, Anggraeni J, Khoirunnas RF, et al. (2010) Identification and Optimization of Indigenous Probiotic Bacteria Against Vibriosis Syndrome Isolated from Litopenaneus vannamei Hatchery in Situbondo, East Java, Indonesia. Proceeding of the 3rd ICMNS.

13. Suantika G, Astuti DI, Arief RR, Rusni M, Turendro OR (2012) Use of Zero Water Discharge Technology through the Application of Nitrifying Bacteria and Textile Vertical Substrate in Grow-Out Phase of Macrobrachium rosenbergii De Man. J Aquacult Res Dev 3:139.

14. Cappucino JG, Sherman N (2005) Microbiology, a Laboratory Manual. USA Pearson Benjamin Cummings.

15. Wyban J (1992) Proceedings of the Special Session on Shrimp Farming. World Aquaculture Society, Baton Roung, LA, USA.

16. Chien YH (1992) Water Quality Requirements and Management for Marine Shrimp Culture. Water Quality Management Review. Department of Aquaculture, National Taiwan Ocean University.

17. Wyk PV, Hodgkins MD, Laramore R, Main KL, Mountain J, et al. (1999) Farming Marine Shrimp in Recirculating Freshwater Systems. Harbor Branch Oceanographic Institution: Florida.

18. Das S, Lyla PS, Khan SA (2006) Application of Streptomyces as a probiotic in the laboratory culture of Penaeus monodon (Fabricius). Israeli Journal of Aquaculture-BAMIDGEH 58: 198-204.

19. Wyban J, Sweeney JN (1991) Intensive shrimp production technology: the Oceanic Institute shrimp manual. Hawaii: Oceanic Institute.

20. Madigan M, Martinko J (2009) Brock Biology of Microorganisms. San Fransisco: Benjamin Cummings.

21. Bitzer J, Grosse T, Wang L, Lang S, Beil W, et al. (2006) New aminophenoxazinones from a marine Halomonas $\mathrm{sp}$ : fermentation, structure elucidation, and biological activity. J Antibiot (Tokyo) 59: 86-92.

22. de Carvalho CC, Fernandes $P$ (2010) Production of metabolites as bacteria responses to the marine environment. Mar Drugs 8: 705-727. 
Citation: Suantika G, Aditiawati P, Astuti DI, Khotimah ZF (2013) The Use of Indigenous Probiotic Halomonas aquamarina and Shewanella algae for White Shrimp (Litopenaeus vannamei Boone) Hatchery Productivity in Zero Water Discharge System. J Aquac Res Development 4: 194 doi:10.4172/2155-9546.1000194

Page 8 of 8

23. Zhang L, Tan BP, Mai KS, Ai QH, Zhang WB, et al. (2008) Screening and Identification of a Potential Probiotic in Shrimp, Fenneropenaeus chinensis. Periodical of Ocean University of China 38: 225-231.

24. Zhang L, Kangsen M, Tan B, Qinghui A, Chiengzhien Q, et al. (2009) Effects of Dietary Administration of Probiotic Halomonas sp. B12 on the Intestinal Microflora, Immunological Parameters, and Midgut Histological Structure of Shrimp, Fenneropenaeus chinensis. J World Aquacult Soc 40: 58-66.

25. Gram L, Bundvad A, Melchiorsen J, Johansen C, Fonnesbech Vogel B (1999)
Occurrence of Shewanella algae in Danish coastal water and effects of water temperature and culture conditions on its survival. Appl Environ Microbiol 65 3896-3900.

26. Shakibazadeh S, Saad CR, Annie C, Kamarudin MS, Sijam K, et al. (2008) Evaluation of in vitro Vibrio static activity of Shewanella algae isolated from healthy Penaeus monodon. African Journal of Biotechnology 7: 3952-3961.

27. Turick CE, Caccavo F Jr, Tisa LS (2008) Pyomelanin is produced by Shewanella algae $\mathrm{BrY}$ and affected by exogenous iron. Can J Microbiol 54: 334-339. 